\title{
Doble sistema pieloureteral bilateral incompleto
}

\author{
García Rodríguez J, Álvarez Múgica M, Miranda Aranzubiz O, González Álvarez R.
}

Servicio de Urología. Hospital Central de Asturias.

Actas Urol Esp. 2008;32(9):953

$\mathrm{L}$ a duplicación completa o incompleta del uréter es una de las malformaciones congénitas más comunes del tracto urinario. En adultos la incidencia es de 0,8\%, es más frecuente en mujeres siendo la duplicación unilateral unas seis veces más frecuente que la bilateral. Puede tener un origen genético y ser heredada de forma autosómica dominante con penetrancia incompleta.

El tipo incompleto se debe a una bifurcación de la yema ureteral antes de que alcance el blastema metanéfrico, en este caso los uréteres se fusionan antes de llegar a la vejiga y desembocan en un único orificio. En la completa, la presencia de dos yemas ureterales conduce a la formación de dos uréteres y dos pelvis renales completamente separadas.

Muchos pacientes con duplicación del uréter son asintomáticos, pero a veces, provoca infecciones per- sistentes o recurrentes; la incidencia de reflujo es mayor en pacientes con duplicación ureteral completa y la orina por lo general refluye hacia el uréter del polo inferior debido a su posición externa y su túnel submucoso más corto.

Presentamos las imágenes de un paciente que consultó por cólico renal derecho objetivandose en la urografía intravenosa un doble sistema pieloureteral bilateral incompleto (Figs. 1 y 2).

Correspondencia autor: Dr. J. García Rodríguez Servicio de Urología

Hospital Central de Asturias

Celestino Villamil, s/n - 33006 Oviedo (Asturias)

Tel.: 985108000

E-mail autor: jgrmed@hotmail.com

Información artículo: Imágenes en Urología

Trabajo recibido: junio 2008

Trabajo aceptado: julio 2008

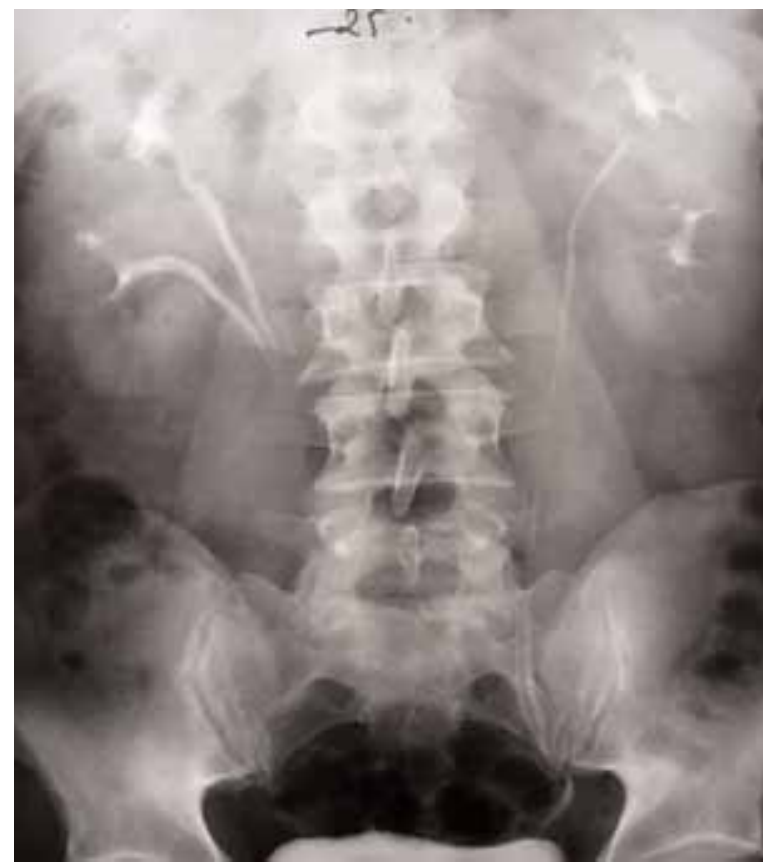

FIGURA 1. Imagen de urografia donde se objetiva doble sistema.

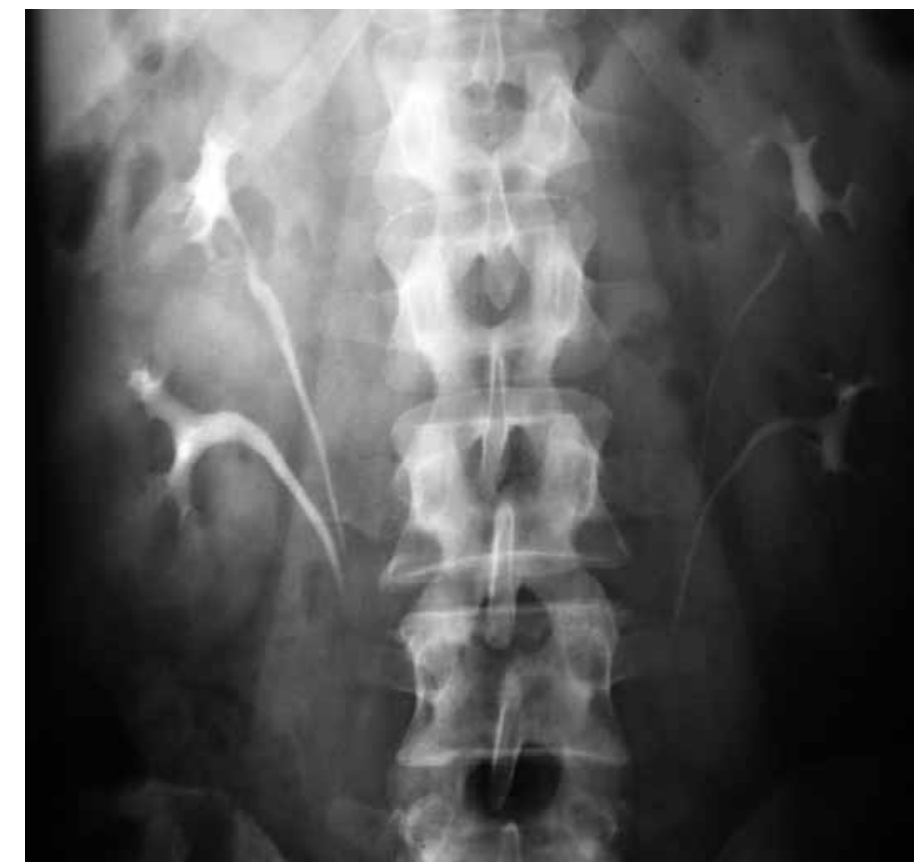

FIGURA 2. Doble sistema pieloureteral bilateral. 